\title{
Identifikasi Pergeseran Fungsi Bangunan Rumah Adat Bantayo Pobo'ide di Kabupaten Gorontalo
}

\author{
Disusun oleh : \\ Rahmawati Eka ${ }^{1}$, Hamsir Saleh ${ }^{2}$ \\ Dosen Arsitektur Program Studi Teknik Arsitektur ${ }^{1}$, \\ Dosen Informatika/ Program Studi Teknik Informatika ${ }^{2}$ \\ Universitas Ichsan Gorontalo ${ }^{1}$ dan 2 \\ INDONESIA \\ alen.arsico@gmail.com
}

\begin{abstract}
ABSTRAK
Tujuan penelitian mengidentifikasi fungsi utama bangunan rumah adat Bantayo Pobo'ide dan sebab akibat pergeseranfungsi bangunan rumah adat Bantayo Pobo'ide.Metode penelitian adalah analisis deskriptif yang digunakan untuk mendeskripsikan hasil penelitian dan wawancara langsung secara mendalam bersama narasumber (dewan adat Gorontalo) dengan pendekatan paradigma rasionalistik melalui pengumpulan data dengan wawancara tidak terstruktur, observasi lapangan kemudian strukturisasi data, serta konfirmasi data dengan kenyataan di lapangan dan pandangan tokoh adat. Hasil penelitian menjelaskan fungsi bangunan sebagai pusat kegiatan adat, museum, tempat penyimpanan semua jenis benda peninggalan adat, pusat pengembangan industri kerajinan tradisional daerah dan sebagai pusat pengembangan pariwisata. Identifikasi temuan pergeseran fungsi bangunan saat ini terjadi pada fisik dan non fisik. Pada fisik bangunan yaitu bantayo pobo'ide menjadi rumah ilmu, rumah ancaman dan menjadi fasilitas umum baik untuk masyarakat maupun pemerintah kabupaten untuk kepentingan kegiatannya. Non fisik terjadi pada lingkungan sekitar bangunan yaitu dengan adanya taman budaya namun tidak berbudaya yang membuat kharismatik bantayo pobo'ide menjadi tenggelam, akibatnya terjadi pergeseran nilai budaya karena tidak sesuai lagi dengan falsafah adat Gorontalo, yaitu adati hula-hula'a to sara'a, sara'a hula-hula'a to Quru'ani.
\end{abstract}

Kata Kunci : Fungsi utama, Pergeseran Fungsi, Bantayo Pobo’ide

\section{PENDAHULUAN}

Rumah adat merupakan bangunan rumah yang mencirikan atau khas bangunan suatu daerah. Di Indonesia rumah adat adalah salah satu yang melambangkan kebudayaan dan ciri khas masyarakat setempat. Indonesia dikenal sebagai Negara yang memiliki keragaman dan kekayaan budaya. Rumah adat merupakan salah satu ciri khas suatu daerah untuk melambangkan budayanya, agar dapat membedakan antara budaya daerah tersebut dengan budaya daerah yang lain. Adapun pada artikel lain yang membahas topik serupa, Sarwo (dalam Budihardjo, 1998) yang menyatakan bahwa rumah merupakan suatu bangunan, tempat manusia tinggal dan melangsungkan kehidupannya. Di samping itu, rumah juga merupakan tempat berlangsungnya proses sosialisasi pada saat seorang individu diperkenalkan kepada norma dan adat kebiasaan yang berlaku di dalam suatu masyarakat.

Di Bali, khususnya di desa Kadewataan, Ubud, nilai- nilai budaya lokal masih dipertahankan, tetapi seiring permintaan pasar pariwisata global, perubahan pun menerpa pada aspek arsitektural rumah Adat-nya, Deny Martinus, 2010.

Pengaruh moderenisasi menyebabkan 
terjadinya perubahan yang cukup signifikan pada fungsi rumah Adat di Bali, maka oleh itu penelitian ini akan mengkaji perubahanperubahan fungsi di desa daerah Ubud tersebut, Deny Martinus, 2010.

Bangunan-bangunan yang ada pada rumah tradisional Bali mengalami perubahan fungsi karena kebanyakan digunakan sebagai tempat penginapan wisata mancanegara. Seperti contohnya bale dauh yang merupakan area tidur, dan bahkan umah meten yang berfungsi sebagai tempat penyimpanan benda-benda pusaka, seringkali telah berubah menjadi area untuk fasilitas duduk, Deny Martinus, 2010. Dengan demikian dapat dikatakan bahwa sebagian besar arsitektur rumah tinggal di desa Kadewataan Ubud merupakan arsitektur Bali Kanonik, yang walaupun aturan-aturan adat dalam pembangunannya masih dipertahankan namun fungsinya telah berubah. Masyarakat di Kampung Kauman yang melakukan pergeseran fungsi rumah dipengaruhi oleh letak Kampung Kauman yang strategis dimana perkembangan kawasan tersebut tidak terlepas dari perkembangan Pasar Johar yang berdekatan dengan Kampung Kauman, Hapsari Amierul, 2012. Faktor lain yang mempengaruhi masyakarat dalam melakukan pergeseran fungsi rumah adalah faktor lama tinggal dan status kepemilikan rumah. Lama tinggal menjadi faktor yang mempengaruhi karena mayoritas masyarakat yang tinggal di Kampung Kauman selama lebih dari 20 tahun dapat melihat perkembangan Kauman dan peluang yang baik dalam membuka usaha di kawasan tersebut, Hapsari Amierul, 2012. Berdasarkan pengamatan awal dan wawancara diketahui rumah adat suku Gorontalo seperti kurang diperhatikan oleh masyarakat khususnya pemerintah Gorontalo itu sendiri. Hanya ada beberapa orang saja yang masih peduli dengan keberadaannya dengan melakukan kegiatan berkesenian seperti persiapan dalam mengikuti lomba musik tradisional, pemajangan hasil karya para orang tua terdahulu seperti berbagai macam jenis buku cerita rakyat Gorontalo, buku pendidikan budaya Gorontalo dan benda-benda purbakala lainnya. Kondisi saat ini sangat memprihatinkan dan patut diperhatikan dengan standar rumah adat sebagai cagar budaya.

Dari penjabaran sebelumnya dapat diketahui bahwa rumah adat Gorontalo sudah tidak sesuai fungsinya dan minimnya pengetahuan masyarakat Gorontalo tentang budaya yang terkandung pada arsitektur rumah adatnya. Kurangnya keperdulian masyarakat untuk melestarikan benda cagar budaya daerah sebagai unsur budaya nasional dan mengupayakan daerah ini menarik bagi wisatawan yang ingin berkunjung ke Gorontalo. Untuk itu, penelitian ini dilakukan guna untuk mengidentifikasi fungsi utama rumah adat pada awal pembangunan, fungsi rumah adat pada zaman sekarang dan perubahan atau pergeseran fungsi dalam rumah adat Bantayo Pobo'ide di kabupaten Gorontalo/Limboto serta jika ada maka apa penyebabnya dan akibatnya.

\section{METODE PENELITIAN}

Metode yang dipakai dalam penelitian 
RADIAL - juRnal perADaban saIns, rekayAsa dan teknoLogi Sekolah Tinggi Teknik (STITEK) Bina Taruna Gorontalo VOLUME 7 NO. 2 Desember 2019

adalah analisis deskriptif yang digunakan untuk mendeskripsikan hasil penelitian dari wawancara langsung secara mendalam bersama narasumber (dewan adat Gorontalo) untuk mengungkap fungsi utama rumah adat Bantayo Pobo'ide. Pendekatan penelitian menggunakan paradigma rasionalistik untuk mengungkap fungsi utama pada awal pembangunan dan mengidentifikasi pergeseran fungsi bangunan dan sebab akibat dari pergeseran fungsi tersebut. Penelitian menggunakan pedoman teori rumah, rumah adat, arsitektur tradisional, dan kebudayaan yang berkaitan erat dengan hasil penelitian nanti, akan dilihat nilai budaya Gorontalo yang bergeser seperti apa saja, dan dapat menjawab rumusan masalah penelitian yaitu penyebab dan akibat dari pergeseran fungsi bangunan bantayo pobo'ide.

\section{TEMUAN DAN PEMBAHASAN}

\section{Identifikasi fungsi dulu/masa kerajaan atau} pada awal pembangunan rumah adat bantayo pobo'ide.

a) Sebagai pusat kegiatan adat, dalam arti bahwa semua kegiatan yang bersifat adat diselenggarakan terpusat di gedung ini.

b) Sebagai museum, tempat penyimpanan semua jenis benda peninggalan adat, tempat menyimpan catatan yang bernilai sejarah, termasuk sebagai tempat menyimpan sangsaka merah putih yang pernah dikibarkan untuk pertama kalinya di daerah ini pada tanggal 23 Januari 1942.

c) Sebagai pusat pengembangan industri kerajinan tradisional daerah seperti tenunan, kerawang, anyaman.

d) Sebagai pusat pengembangan pariwisata daerah, sehingga bangunan ini menjadi tempat pementasan kebudayaan dan kesenian daerah.

\section{Identifikasi temuan pergeseran fungsi} bangunan pada masa pemerintahan/ dan atau sampai sekarang.

a. Menjadi "rumah ilmu". Bagi masyarakat Gorontalo dan masyarakat pendatang bantayo pobo'ide dijadikan sebagai objek penelitian untuk studi kasus para siswasiswi SMA dan SMK, mahasiswa dan peneliti, objek videography, objek foto kontes, objek wisata bagi wisatawan asing, objek selfie bagi anak-anak muda dan orang tua sekalipun. Bantayo pobo'ide adalah rumah ilmu bagi masyarakat Indonesia khususnya untuk provinsi Gorontalo. Hal ini disebabkan begitu banyak kegiatan dan agenda, baik itu dari pemerintahan maupun masyarakat umum seperti anak sekolahan sampai dengan perguruan tinggi menjadikan bangunan ini sebagai objek kepentingan dari kebutuhan mereka tersebut.

b. Menjadi "rumah ancaman". "kharismatik suatu kabupaten dalam mempertahankan identitasnya jika masyarakat menghargai peninggalan zaman dahulu, tidak akan ada masa depan dan generasi penerus jika tidak berawal dari zaman dahulu pula". Kondisi yang semrawut dan sangat memprihatinkan pada saatsaat tertentu. Siang hari hanya ada beberapa orang yang terlihat mengamati ataupun berkunjung melihat kondisi bangunan dan kegiatan ini berlangsung secara bergantian, ada yang datang 
kemudian yang selesai berkunjung pergi dan ketika malam hari hanya beberapa sudut saja terdapat lampu penerang. Pada sulambe kanan bangunan hampir tidak ada penerangan sama sekali akibatnya bagian ini seringkali dijadikan tempat pojokan "mesum" bagi orang-orang yang tidak bertanggung jawab, sedangkan sulambe kiri bangunan terdapat penerang khusus dari salah seorang penjual snack dan minuman. Entah hal ini diketahui oleh pemerintah kabupaten ataupun tidak sama sekali.

c. Tempat umum kedinasan kabupaten Gorontalo. bangunan dijadikan tempat atau sekretariat ketika ada event besar kabupaten seperti festival danau Limboto.

d. Kegiatan lansia. Dalam hal ini dikatakan pergeseran fungsi bangunan, para orang tua melakukan pengajian sekali dalam setiap bulannya. Pengajian oleh pengelola ibu haja Rukmin otayya yang juga sebagai pengelola tetap bantayo pobo'ide. Beliau berusaha mengadakan kegiatan islami ini secara rutin sebulan sekali demi menghidupkan fungsi bangunan tua yang semakin hari semakin menurun dan tenggelam kharismatik dan estetika dari bantayo pobo'ide, kegiatan itu baik dari pengajian, doa rawatib (doa untuk keselamatan negri), doa barjanji sampai dengan hatam Qur'an.

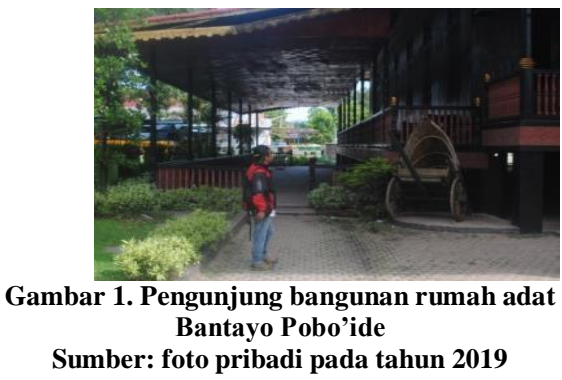

e. Tempat latihan paduan suara

f. Kawasan bangunan biasa menjadi tempat senam atau aerobik bagi masyarakat setempat.

Penjabaran diatas dan temuan pergeseran fungsi bangunan pada objek penelitian dapat dikatakan bahwa bantayo pobo'ide sudah menjadi fasilitas umum yang hampir tidak di maintanance fisiknya.

Pembahasan penyebab dan akibat dari pergeseran atau perubahan fungsi pada bangunan rumah adat bantayo pobo'ide.

Dalam proses yang dimulai dengan survey awal hingga beberapa kali survey lanjutan dan dilakukan pengamatan pada objek penelitian di dapat beberapa faktor penyebab pergeseran fungsi pada bangunan bantayo pobo'ide sebagai berikut: Kegiatan dalam lingkungan rumah adat bantayo pobo'ide adapun faktor yang di dapatkan adalah manusia dan bangunan itu sendiri dimana ada keterkaitan yang menjadi penyebab pergeseran fungsi bangunan.

a) Perilaku masyarakat.

Pengunjung setempat, pengunjung dari kota Gorontalo maupun dari warga asing/tourist memiliki sifat dan karakter masing-masing dalam berperilaku ketika berada di bangunan rumah adat Bantayo Pobo'ide. Contohnya ada yang ingin berkunjung melihat bangunan, menikmati landscape bangunannya dan adapun yang sampai mencari tahu kondisi bangunan, bahkan ada yang menyalahgunakan tempat ini untuk halhal yang negatif. 
RADIAL - juRnal perADaban saIns, rekayAsa dan teknoLogi Sekolah Tinggi Teknik (STITEK) Bina Taruna Gorontalo VOLUME 7 NO. 2 Desember 2019

b) Kegiatan yang dilakukan di lingkungan bangunan bantayo pobo'ide yang sesuai dengan kebutuhan dan keinginan masyarakat pengunjung, selera, suasana dan kondisi lokasi. Hal ini bisa dikatakan ada pergeseran nilai budaya Gorontalo yang sangat erat kaitannya dengan falsafah adat "adati hula-hula'a to sara'a, sara'a hula-hula'a to quru'ani”. Demikian dijelaskan pergeseran nilai budaya, seperti yang telah di jabarkan pada temuan pergeseran fungsi bangunan, dalam nilai budaya pun terjadi. Hal ini bisa dilihat pada (gambar 2) sangat jelas adanya bangunan baru yaitu "taman budaya", namun jika dilihat secara jelas hampir tidak ada ide bentuk ataupun pola tata massa yang mengambil ide desain dari budaya Gorontalo itu sendiri. Hanya ada beberapa perkerasan atau hardscape yang di desain mengikuti bentuk salah satu alat musik tradisional Gorontalo dan ditambah dengan bangunan menara yang dihiasi lampu warnawarni serta air mancur yang mengeluarkan air berwarna ketika malam hari.

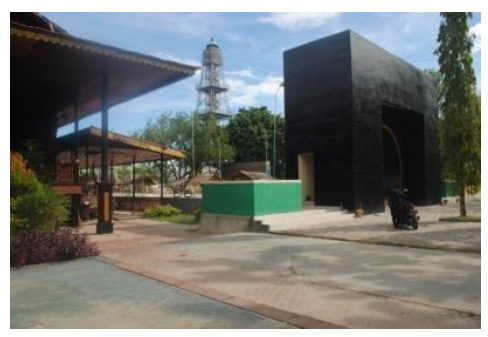

Gambar 2. Kondisi saat ini pada lingkungan rumah adat Bantayo Pobo'ide

Sumber: foto pribadi pada tahun 2019

Pergeseran pada nilai budaya karena tidak menjadikan falsafah adat sebagai pedoman desain secara makro atau keseluruhan.
Dapat dijelaskan contoh nyata pada objek, ketika ibadah sholat sementara berlangsung, banyak bunyi-bunyian yang secara bersamaan pula terdengar bahkan menyaingi suara yang berasal dari mesjid yang berada tepat didepan bangunan taman budaya dan berada tepat dibelakang rumah adat bantayo pobo'ide tersebut yang sebenarnya tidak pernah terjadi sebelumnya . Hal yang paling di sayangkan ketika ada kegiatan pengajian yang berlangsung di bantayo pobo'ide sering terganggu oleh suara bising, aktivitas penyedia jasa dan pengunjung dari lingkungan taman tersebut.

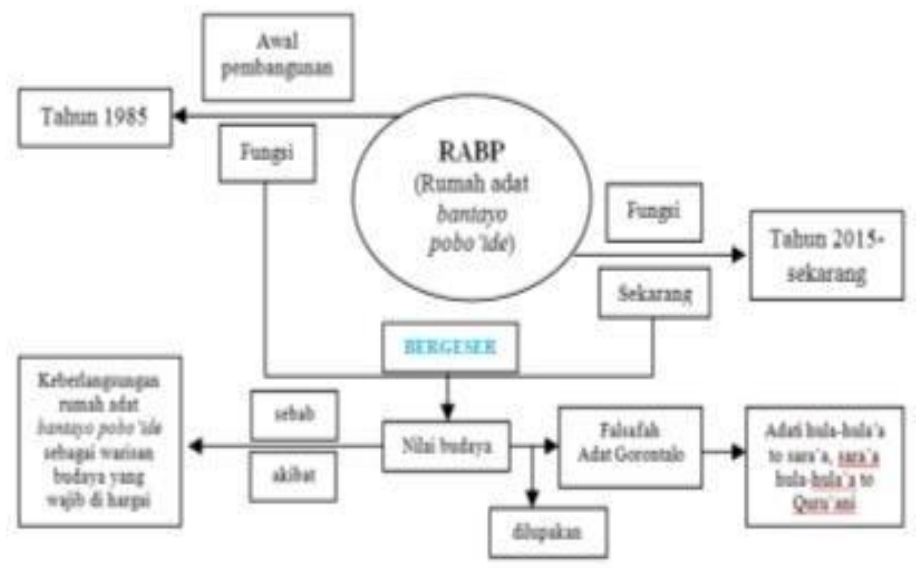

Gambar 3. Grafis Pergeseran RABP Sumber: Desain pribadi pada tahun 2019

c) Kurangnya perhatian dari pengelola bangunan terhadap fungsi bangunan. Kenyataan pada bangunan rumah adat sudah ada beberapa lapak jualan yang masih sepi pada siang hari, entah hal ini sudah diketahui dan memperoleh izin oleh pemerintah setempat ataupun pengelola bangunan. Dari kondisi ini sudah menjadi bukti bahwa salah satu fungsi bangunan berubah bahkan semakin hari, semakin kurang pengetahuan masyarakat akan 
pentingnya menghargai warisan budaya masalalu yang sudah di upayakan oleh pemerintah pada zaman dahulu untuk dipertahankan.

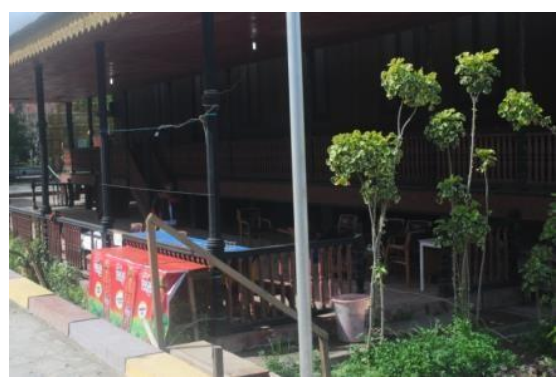

Gambar 4. Lapak yang dibangun oleh masyarakat yang tidak bertanggung jawab

Sumber: foto pribadi pada tahun 2019

\section{KESIMPULAN}

Peninggalan masalalu saat ini hampir tidak diperdulikan lagi bahkan di acuhkan estetika karakteristik fisiknya akibat kurangnya pengelolaan dan maintenance. Bangunan yang dulunya sangat dihargai dan sekarang, bahkan untuk dilihat pun tidak. Kekurangan ini berimbas pada keberlangsungan bangunan rumah adat bantayo pobo'ide. Pergeseran fungsi bangunan yang di akibatkan oleh kegiatan fisik dan non fisik yang berasal dari kegiatan manusia dan kondisi lingkungan sekitar, membuat pergeseran nilai budaya pun ikut bergeser karena sudah tidak sesuai lagi dengan falsafah adat Gorontalo itu sendiri. Hal ini jika dibiarkan akan membuat daerah kehilangan identitasnya masa lalu yang sangat penting untuk masa depan. Harapan peneliti bagi pemerintah kabupaten sangatlah besar untuk perhatian utamanya khususnya bangunan cagar budaya tersebut. Sebagai penggiat local wisdom hati ini hancur dengan melihat kondisi bantayo pobo'ide saat ini dibandingkan dengan yang dulu.

\section{KERANGKA HASIL PERGESERAN}

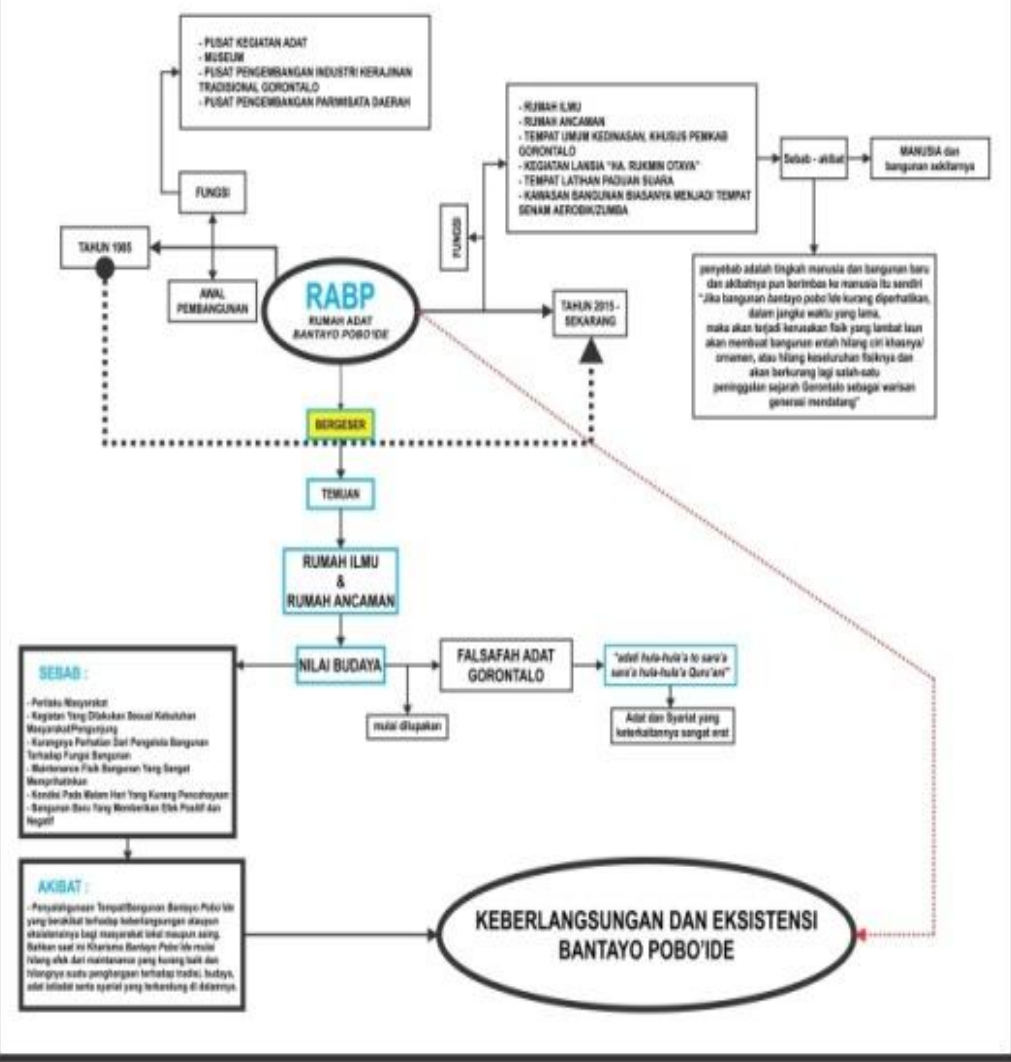

Gambar 5. Grafis Kerangka Hasil Sumber: Desain pribadi pada tahun 2019

\section{UCAPAN TERIMAKASIH}

Peneliti berbangga diri dan berterima kasih kepada ristek dikti atas capaian saat ini yaitu dengan menjadi salah satu peraih dana hibah penelitian kompetitif nasional dengan skim penelitian dosen pemula. Harapan bisa menjadi kontributor untuk penelitian terbaru di dalam dunia penelitian.

\section{DAFTAR PUSTAKA}

Amelia, C. (2010). Perubahan Fungsi Ruang Rumah Adat Bali Akibat Program Studi Desain Interior Fakultas Seni Rupa Dan Desain.

Apriyanto, Joni. 2012. Sejarah Gorontalo Modern Dari Hegemoni Kolonial Ke Provinsi. Yogyakarta: Penerbit Ombak 
Budihardjo. (1994). Percikan Masalah arsitektur, Perumahan Perkotaan, Penerbit Gajah Mada University, Press

Iii, B. A. B. (2009). Bab iii metode penelitian 3.1. 12-17.

Karsono, D. (n.d.). Pergeseran Nilai Budaya Pada Banguna Rumah Tradisional Jawa. -, 1-6. Keguruan, F., \& Banyuwangi, U. P. (n.d.). 1, 2 1. 8894. https://doi.org/10.31227/osf.io

Moehadjir, Noeng. (1989). Metodologi Penelitian Kualitatif: Telaahan Positivistik, Rasionalistik dan Phenomenologik. Yogyakarta: Rake Sarasin.

Rahaju B.U.K., Sri. (2010). "Arsitektur Tradisional di Indonesia: Gagasan dan Artiefak Budaya", Hanan, Himasari. Sejarah, Teori dan Kritik Arsitektur. Bandung: Kelompok Keahlian Sejarah, Teori dan Kritik Arsitektur SAPPK ITB.

Sugiyono. (2006). Metode Penelitian Kuantitatif, Kualitatif dan R \& D.
Bandung: Alfabeta.

Tribinuka. (2008), Pendayagunaan Arsitektur Nusantara Untuk Proses Perancangan Mutakhir. Makalah ini disampaikan pada Seminar Nasional Ke-Bhinekaan Bentuk Arsitektur Nusantara, Surabaya: 12-13 September 2008

Wuisman, Jan J.M. (2007). "The Past in the Present: the Place and Role of Indonesian Vernacular Architectural Traditions and Building Styles of the Past in the Present", Nas, Peter J.M. (ed). The Past in the Present: Architecture in Indonesia. Leiden: KITLV Press.

\section{Wawancara langsung :}

Bersama, Mantan Dewan Adat Kabupaten Gorontalo (H.Yamin Husain, SE)

Bersama, Bate Lo Hulondalo atau Juru Bicara

Tokoh Adat Gorontalo (H. Dadi Kasim Usman)

Bersama, Dewan Adat Kota Gorontalo (Drs. H. Karim Pateda, MM.

Pensiunan guru (seniman) Talib R Eka 